\title{
Investigating hsCRP as a clinical inflammation marker for human Bisphenol A food contamination offers protocol suggestions for conducting replicable, causal dietary intervention studies
}

\author{
W. Lewis Perdue, ${ }^{(1)^{*}}$ Victor I. Reus, ${ }^{(2)}$ Rebecca L. Yeamans-Irwin ${ }^{(3)}$
}

\section{Author Information}

(1)* W. Lewis Perdue, Center for Research on Environmental Chemicals in Humans, Sonoma, USA.

(2) Victor I. Reus, Department of Psychiatry, UCSF Weill Institute for Neurosciences, University of California, San Francisco (UCSF) School of Medicine, San Francisco, USA

(3) Rebecca L. Yeamans-Irwin. Center for Research on Environmental Chemicals in Humans, Sonoma, USA.

* Corresponding author: W. Lewis Perdue, Center for Research on Environmental Chemicals in Humans, 811 W. Napa St., Suite G, Sonoma, CA 95476, USA. lewis.perdue@crechcenter.org. Phone: +1 (707) 326-4503

Disclosure: Authors declare no conflicts or competing interests in this work. This study was approved by the IRB/Committee on Human Research at the University of California San Francisco School of Medicine, IRB \#: $15-17703$

\begin{abstract}
:
Dietary intervention studies thus far have failed to be replicable or causal. The results, therefore, have failed to provide clinicians and the general public with consistent and useful information on which to base reliable food-related health decisions. This is particularly relevant regarding plastic-derived chemicals (PDCs), such as Bisphenol A, now that the federal CLARITY-BPA program has failed to achieve scientific consensus. Investigators propose a novel human dietary protocol that is both replicable and causal, based upon BPA's demonstrated inflammatory effects in humans. This first-of-a-kind dietary intervention study explores a potential causal relationship between human serum levels of BPA and High-Sensitivity C-Reactive Protein (hsCRP), a proven clinical indicator of inflammation. Investigators used the equivalent of a USDA-defined "typical diet" followed by a PDC-reduced diet to compare blood levels of hsCRP. This proof-of-concept investigation is the first to use an easily accessible, medically-accepted clinical laboratory test to directly measure human health effects of PDC reduction. Unexpected new complications discovered during the investigation indicate that these results may yet be inconclusive for direct causal relationship. However, the novel lessons and techniques developed as a result of those discoveries offer further specific and improved methods and best practices that can enable future dietary interventions to produce replicable, causal results.
\end{abstract}

\section{BACKGROUND}

Exposure to environmental chemicals in the U.S. is widespread. ${ }^{1}$ As of June 2020, more than 86,000 chemicals were approved for use in the United States, ${ }^{2}$ and at least 4,000 of those are 
medRxiv preprint doi: https://doi.org/10.1101/2020.10.25.20212282; this version posted October 27, 2020. The copyright holder for this preprint (which was not certified by peer review) is the author/funder, who has granted medRxiv a license to display the preprint in perpetuity.

It is made available under a CC-BY-NC-ND 4.0 International license .

Plastic-Derived Chemicals (PDCs) present in food contact materials. ${ }^{3,4,5}$ PDCs such as Bisphenol A (BPA), phthalates, and other plastic derivations are present in approximately $97 \%$ of the U.S. population. 6,7

Significantly, in a 10-year observational study of 3,883 adults in the United States, participants with higher urinary Bisphenol A levels were at a $49 \%$ greater risk for death from all causes. ${ }^{8}$

PDCs such as BPA are increasingly classified as endocrine disrupters, even in low-level concentrations. $^{7,9}$

Human and animal studies have also identified PDCs compounds as contributors to cancer ${ }^{10-21,}$ cardiovascular disorders $^{12,22-29}$, obesity ${ }^{30-36}$, type 2 diabetes $^{35,37-39}$, metabolic syndrome si-33,40,41, $^{3}$ neurological and behavioral disorders ${ }^{42,43}$ also including Alzheimer's Disease ${ }^{12,40,44-48}$, as well as reproductive $^{13,49-56}$, and developmental disorders ${ }^{13,57-62}$ and allergies ${ }^{63-70}$.

No scientific agreement exists about the health effects of most of these PDCs ${ }^{71}$. That includes BPA which, because of its ubiquity, has been singled out for special attention by the U.S. government as evidenced by the CLARITY-BPA ${ }^{72}$ program that was intended to resolve a contentious scientific divide on safety.

However, that divide still exists today as regulatory investigators have deemed current exposure levels as harmless ${ }^{73-75}$ while university-affiliated biomedical scientists continue to disagree ${ }^{76}$ and find BPA a public health threat. ${ }^{77-79}$

\section{Routes of Exposure}

Exposure to BPA and other PDCs come from both dietary and non-dietary sources. ${ }^{80}$

BPA and other PDCs are found in household products such as detergents, cosmetics, lotions, and fragrances ${ }^{81}$, as well as in water bottles and baby bottles, thermal paper for printers, dental sealants, and medical devices including intravenous fluid and chemotherapy bags and tubing. $7,15,82-86$

Food and beverage packaging are substantial contributors to PDC physiological burdens. ${ }^{7,87-91}$ Consumers are exposed to many PDCs from leaching and migration of chemicals from plastics and other food contact materials. ${ }^{7,88-96}$

Exposure routes for food and beverages also include preservatives, flavorings, scents, texture enhancers, and coloring agents ${ }^{5}$, migration/leaching of chemicals from harvesting and processing $^{87}$, as well as home food-handling which can accelerate migration through heating, microwaving, ultraviolet light exposure (including fluorescent lighting), and the contact of contaminated oils and alcohols with plastics.

Ultra-processed foods (UPFs) that have undergone substantial chemical or physical modification through manufacturing methods also have numerous avenues of PDC contamination due to residual contamination in additives, from additional contacts with plastic components, and from 
the addition of fats which facilitate the transfer of lipid-soluble polymer components into the UPFs. ${ }^{98,99}$

UPFs and PDCs are both associated with many non-communicable dietary-related diseases and syndromes including obesity, ${ }^{100-107}$ diabetes, ${ }^{108-110}$ cardiovascular disease, ${ }^{111-113}$ and cancer $^{10,18,114,115}$.

\section{Could standard human clinical blood tests resolve the clarity issues with CLARITY?}

As a result, the current CLARITY-BPA debate centers on experimental protocol flaws, contrasting interpretations of published science, confounding factors, sources of contamination and other fine points of scientific experimental design as well as practice and fundamental differences concerning the existence of non-monotonic behavior of substances present at very low levels.

Interpreting these factors by lay audiences can be all but impossible. Likewise, the current internecine arguments among scientists are unlikely to sway public, governmental or manufacturing opinion one way or another because:

(1) There are no direct human health effects studies of BPA and other PDCs.

(2) The CLARITY program has been criticized as irrelevant due to the failures of translating murine results to humans. ${ }^{116}$ Indeed, other published reports find that murine model results do not to translate accurately to humans as much as $92 \%$ of the time. ${ }^{117}$ Even pre-clinical research trials fail to be replicable ${ }^{118}$ from $51 \%$ to $89 \%$ of the time. ${ }^{119-120}$

(3) Human dietary intervention studies, which might be able to shed light on the issue, have replication and scientific rigor flaws that prevent them from offering reliable clinical conclusions. ${ }^{121,122}$

\section{Enter the humble clinical blood test}

Significantly, a source of reproducible, causally connected, and clinically valuable direct human data may lurk in standard laboratory blood profiles.

Because of the role of inflammation in many BPA-associated non-communicable diseases, HighSensitivity C-Reactive Protein (hsCRP) may fill the need for clinical insights into numerous PDC-linked inflammation-linked conditions cardiovascular disease, ${ }^{123-125,131,137}$ Type 2 Diabetes, ${ }^{126-127}$ cancer, ${ }^{126,129,137}$ Alzheimer's Disease, ${ }^{130,132}$ depression, and suicide, ${ }^{133-136}$ and auto-immune diseases ${ }^{137}$ including IBD, ${ }^{138}$ rheumatoid arthritis, ${ }^{139}$ and lupus. ${ }^{140}$

In addition, BPA has been found to activate the same NLRP3 inflammasome pathway activity ${ }^{141}$ implicated in "cytokine storms" which develop in research suspects along with bradykinin disorders $^{142}$ as causes underpinning some of the most serious of COVID-19 cases. $^{143-145}$

\section{OBJECTIVES}


medRxiv preprint doi: https://doi.org/10.1101/2020.10.25.20212282; this version posted October 27, 2020. The copyright holder for this preprint (which was not certified by peer review) is the author/funder, who has granted medRxiv a license to display the preprint in perpetuity. It is made available under a CC-BY-NC-ND 4.0 International license .

Objective 1, validate marker: Can hsCRP serve as a marker for BPA exposures?

Objective 2, evaluate duration: Is a short (e.g. six-day) trial long enough for an intensive BPA avoidance protocol to affect hsCRP outcome measurements?

Objective 3, improve causality and replication: Can replicability and causality of dietary intervention trials be increased by developing best practices and (for the first time) applying the discipline of standard laboratory practices to the sourcing, preparation, and serving of human food along with their complete data capture and reporting?

\section{METHODS}

Given that the use of clinical blood tests as possible direct human health effects indicators of environmental chemical contamination is an unknown field, investigators felt that a small proofof-concept trial (n-of-1) would be sufficient to test the validity of the concept and protocols before beginning a larger, more expensive study. N-of-1 investigations have found wide acceptance and success in biomedical science ${ }^{146}$ and are proposed as a main tactic in precision medicine ${ }^{147}$ and pharmaceutical research.

This n-of-1, six-day study (SSHS) was approved by the Committee on Human Research/IRB at the University of California San Francisco School of Medicine. ${ }^{148}$ The study consisted of two legs - a three-day "typical American diet" (Typical) with known sources of plastic contamination followed by a three-day intervention diet (Intervention) of foods with measurably reduced BPA contamination.

The study approved was based on a substantially revised protocol designed around a far more tightly controlled investigation. This investigation is intended to overcome inherent limitations on replicability in previously published studies that did not exercise investigator controls or data collection and other documentation involved with the sourcing of food, or its production and serving environment.

This investigation was conducted in a 400-square-foot professional kitchen supervised and directed by investigators in the same manner as a bench lab experiment. Central air with HEPA filters ventilated the kitchen which was also equipped with two standalone HEPA filter machines. A 1,200 cubic-feet/minute, four-centrifugal-fan exhaust hoods were used over an eight-burner natural gas stove. Two electric ovens were used for baking.

Plastic items including utensils, containers, and cookware with non-stick coatings were removed from the kitchen prior to trial onset. Food preparation took place on stainless steel countertops. Kitchen-ready scales were obtained and calibrated using brass gram weights.

Indoor kitchen air quality (via PM2.5 levels) were monitored via sensors from PurpleAir.Com and maintained at an Air Quality Index of 0 . Test subject consumed meals in an adjoining space with identical environmental conditions including the absence of plastic.

\section{A. Menu Determination}

The menu for each of the two diets (Typical and Intervention) was made as identical as feasible. 


\section{Typical:}

The "typical" American diet (i.e. PDC-contaminated diet) was drawn from the United States Department of Agriculture (USDA). ${ }^{149}$ Food for the typical diet was sourced from national brands available at a large national chain store (Safeway) to maximize availability.

\section{Intervention:}

For the intervention diet, the menu from "typical American diet" was adapted to offer replicate food items with reduced or absent PDC contamination.

Intervention food was sourced in accordance with Appendix 2 of the revised protocol. ${ }^{148}$

The extensive requirements of the revised protocol included sourcing food close as possible to its actual production from a vendor capable of shipping nationally. Additionally, the producer:

- Either dry-farmed or used well water for irrigation,

- Did not irrigate with recycled wastewater or biosolids (sewage plant sludge)

- Adhered -- as a minimum -- to USDA organic standards.

Because milk is sourced locally or regionally, even by large chains, milk samples were analyzed via LC-MS/MS performed by Eurofins (https://www.eurofins.com/) to ensure the same or similar BPA quantification. Cheese products were selected from nationally available dairy brands whose milk scored below the limit of quantification (LOQ) in the LC-MS/MS tests.

Fish and seafood were excluded because the environmental pollution variability made it impossible for consistency in BPA exposure.

Carbon-filtered water was used for food preparation and to rinse before use of all dishes, utensils, pots, pans, and food-contact appliances. Multi-ingredient foods, such as a spaghetti and meatball frozen entrees, were "reverse engineered" from the dishes used in the "contamination" leg. Special attention was devoted to the health effects of micro- and nanoplastics, and to minimizing exposure to those particles of undeterminable composition.

\section{B. Food Preparation}

After lengthy research, this study's protocols were extensively revised ${ }^{148}$ to include the development of best practices that included the imposition of specific, rigorous scientific practices common to bench laboratory investigations. This included rigorous requirements for sourcing food and beverages, and the realization that a kitchen needed to be treated as a proper laboratory environment.

This required investigators to train and supervise all kitchen personnel to assure they were capable of precise measurements, and treating ingredients as reagents, recipes as procedures, appliances as equipment, and the paramount requirement to capture detailed and extensive data capture sufficient to allow replication of the trial under the exact same conditions. 
In the kitchen, only glass, stainless steel, aluminum foil, and tight grain maple cutting boards were permitted for food preparation. $100 \%$ cotton dish towels were allowed; paper towels could only be used for cleanup. Vinyl gloves were used for all food preparation but contact with food products was designed to be minimal and incidental.

Intensive treatment of food in the revised protocol ${ }^{148}$ was designed to minimize BPA. For example, fresh organic vegetables were thoroughly rinsed or soaked in filtered water. Solid meat was first wiped with extra virgin olive oil obtained from a local mill which uses no plastic and packs the oil in glass. The meat was then scraped with a metal pastry divider and wiped dry again to remove lipid-solid PDCs such as BPA. Hamburger was prepared fresh using a grinder with all metal food contact surfaces.

No pre-prepared foods were allowed. Pasta and bread were baked using flour from a small mill that grinds wheat with no plastic contact obtained from small local organic, pesticide-free farms.

All measurements (including for liquids) were made by metric weight. All main ingredients were measured to the nearest gram, but small-weight items such as spices, herbs, other seasonings, and other items were measured to the nearest tenth of a gram.

Seasoning was with whole spices and fresh herbs with no PDC exposure grown for the purpose of this study by the investigators. When investigator-grown seasonings were not available, investigators specified organic whole spices (cinnamon sticks, whole nutmeg fruit, peppercorns) and hand ground them after wiping or rinsing with filtered water. Items with known or suspected plastic contamination (such as micro-plastic contamination of table salt ${ }^{150}$ were replaced with suitable reagents from Sigma-Aldrich.

\section{Blood Sampling of Study Participants}

Two blood samples (one for hsCRP and one for BPA levels) were taken from each subject three times during the study: the first day to establish baseline; the last morning after the "typical" menu leg; and the last morning after the intervention leg.

All blood draws (hsCRP and BPA) were made at Sonoma Valley Hospital (SVH - an affiliate of UCSF).

Samples to be analyzed for hsCRP were drawn in light-green-topped tubes with standard concentrations of Li-heparin and centrifuged. Those were analyzed by the UCSF Parnassus campus medical laboratory.

The samples for BPA analysis were drawn by SVH using a vacutainer kit supplied by the lab of a UCSF researcher at the medical school's Mt. Zion campus who had agreed to analyze the samples for BPA. The vacutainer kit was composed of polymers the researcher had found not to leach BPA or other PDC contaminants into the blood samples.

The samples were delivered as virgin whole blood to the UCSF researcher's lab where they were centrifuged and frozen for LC-MS/MS analysis. Samples were hand-delivered within four hours of blood draws. To keep the high cost down, the samples were retained by the UCSF researcher's lab and intended to be run as soon as a sufficient number of additional samples were in hand. 
medRxiv preprint doi: https://doi.org/10.1101/2020.10.25.20212282; this version posted October 27, 2020. The copyright holder for this preprint (which was not certified by peer review) is the author/funder, who has granted medRxiv a license to display the preprint in perpetuity.

It is made available under a CC-BY-NC-ND 4.0 International license .

Originally, the hsCRP and BPA levels from the baseline, typical and intervention legs were to be compared to determine the degree of correlation. However, BPA sample analyses were not made available.

Accordingly, no hsCRP/BPA correlation was possible in this preliminary, proof-of-concept trial. However, correlations between hsCRP and the trial legs are presented as preliminary examination of the hypothesis.

\section{RESULTS}

Levels of hsCRP decreased $21.4 \%$ from baseline to end of the Intervention leg: $1.1 \mathrm{mg} / \mathrm{L}$ from $1.4 \mathrm{mg} / \mathrm{L}$. The results demonstrated a final percentage reduction in hsCRP parallel to (but smaller in magnitude) than that of a major NIH-funded dietary intervention by Hall, et al. ${ }^{105}$ published in 2019 approximately four months prior to our trial. (See Table 1)

\begin{tabular}{|c|c|c|c|c|}
\hline \multicolumn{5}{|c|}{$\mathrm{NIH} /$ Hall versus SSHS } \\
\hline hsCRP (mg/L) & $\mathrm{NIH} /$ Hall & leg delta & SSHS & leg delta \\
\hline \multirow[t]{2}{*}{ baseline } & \multirow[t]{2}{*}{2.7} & & \multirow[t]{2}{*}{1.4} & \\
\hline & & -0.3 & & -0.5 \\
\hline \multirow[t]{2}{*}{ contamination } & \multirow[t]{2}{*}{2.4} & & \multirow[t]{2}{*}{0.9} & \\
\hline & & -0.9 & & 0.2 \\
\hline intervention & 1.5 & & 1.1 & \\
\hline Total Delta & & -1.2 & & -0.3 \\
\hline Total Delta \% & -44.4 & & -21.4 & \\
\hline
\end{tabular}

Table 1: SSHS Study Results Versus Hall et al ${ }^{105}$

\section{Discussion}

This paper discusses a revised version ${ }^{148}$ of a study approved by UCSF-IRB on Nov. 15, 2014. Revisions were necessary because the original protocol was patterned after existing published dietary interventions, ${ }^{73,89,105,150,151}$ which lacked rigorous protocols capable of producing replicable results or credible causal relationships. ${ }^{121,152}$

Protocol revisions for this study were necessary because published dietary interventions involving BPA and other PDCs had relegated food sourcing and preparation to third parties caterers or institutional kitchens - without investigator supervision, training in laboratory procedures, or proper data capture. A study without detailed data on food sourcing, preparation, procedures and serving environment cannot be replicated.

Most of this study's protocol revisions involved developing best practices to bring human dietary interventions in line with the basic scientific rigor required of bench experiments. We believe those changes have made this investigation replicable. 
However, replicable and causal considerations are not the same thing. A post-investigation review of Hall et al., ${ }^{105}$ which was published four months before our trial, indicated that our investigation (as well as Hall et al.,) could not be causal because the "contamination legs" of both studies contained Ultra-Processed Foods which exert the same measurable biomarker influences as BPA. Complicating the situation further,there is the existence of BPA and phthalates in UPFs due to their more extensive plastic contact with processing and packaging.

For these reasons, neither study can conclude whether biomarker changes are causally due to BPA, UPFs, or both. This situation renders as irrelevant a further issue of whether nutritional differences in the two legs of the studies could influence the expression of relevant biomarkers.

Neither this study, nor Hall et al., succeeded in matching the nutritional values of both study legs for calories, total fat, saturated fat, trans fat, sugar, total carbohydrate, dietary fiber, or protein in order to account for possible health effects of those items. But even if investigators had been successful, these eight items are a small subset of the $26,000+$ biochemicals found so far in foods, ${ }^{153}$ many of which are metabolically active and could influence health indicator biomarkers.

This knowledge dictates that establishing valid causal connections will require identical foods in both study legs, with food in the contamination leg dosed with an appropriate amount of the independent variable substance being evaluated for health effects.

The lower overall decrease in hsCRP in our study versus Hall et al., could be attributable to the shorter length of our trial. This may be due to the fact that BPA may have a longer half-life than previously thought. ${ }^{154}$ The lower decline in hsCRP levels in our study versus Hall et al. could have been caused by our shorter trial duration (six days rather than 28) which affects the release of BPA from adipose stores and/or its metabolism. Indeed, the minor increase of hsCRP in the second leg of the trial may indeed be due to the delayed release of BPA from the test subjects' dietary changes.

An alternate explanation rests in the non-monotonic behavior of BPA, in which its effects become more powerful as the concentration falls into a specific range of influence. ${ }^{155,156}$

Non-monotonic behavior is counter-intuitive, but found in other compounds especially those that, like Bisphenol A, exhibit estrogenic effects active in the endocrine system. Breast-cancer treatment tamoxifen, for example, exhibits non-monotonic behavior and is most effective in tiny concentrations. ${ }^{156}$

A final difference between this trial and Hall et al., may be that our trial was interrupted by Northern California wildfires that dramatically increased PM2.5 particulate pollution, a notorious promoter of inflammation. ${ }^{158}$ This exposed the n-of-1 investigator/test to environmental PM2.5 pollution in order to deliver blood draw samples to two UCSF laboratories at the Parnassus and Mt. Zion campuses. Those exposures lasted for a minimum of 2.5 hours on three occasion. That level of exposure may account for the overall smaller decrease in hsCRP in our study versus Hall et al.

\section{Outcomes: Results of study objectives}




\section{Objective 1, validate marker:}

Outcomes: The sourcing, preparation and serving protocols used in the intervention phase indicated that hsCRP levels were affected by the trial legs and may serve as a valid indicator. It is still unknown whether the lowered hsCRP level in our study can be a valid health indicator of human BPA contamination. not only because of confounding UPF factors, but also because the blood samples to be measured for BPA levels were reportedly misplaced by the LC/MS lab of the UCSF researcher who had agreed to process the samples.

However, this trial did reveal a pattern of hsCRP behavior consistent with Hall et al., which measured hsCRP as an indicator of inflammation in a trial of ultra-processed foods.

\section{Objective 2, evaluate duration:}

Outcomes: The study protocol's projections of the metabolic pharmacokinetics of Bisphenol A and hsCRP point to the usefulness of the shortened trial length, although does not specifically confirm a test period as short as 6 days.

\section{Objective 3, improve causality and replication:}

This trial is replicable, but its results - like all other published human dietary interventions does not illustrate acausal effect.

However, this study successfully developed best practices concerning the training and supervision of kitchen staff along with the sourcing, identification, preparation, and serving of foods, the use of scientific protocols, rigorous data capture, and the control of non-dietary exposures to PDCs that can lead to replicability and causality of subsequent dietary intervention trials involving Plastic-Derived Chemicals.

We did attempt to replicate the dietary portion of Hall et al, ${ }^{105}$ but our multiple requests to those investigators for useful information such as recipes, food sourcing never received a reply. The lack of that information along with that trial's lack of use of unsupervised third-party food preparation make it incapable of replication. However, the use of a dormitory setting by Hall et al. ${ }^{105}$ is important in controlling the complicating conditions that could bias a dietary intervention study.

\section{Trials Replication and Causality}

This proof-of-concept trial and associated research indicate that dietary intervention studies as a whole are inherently flawed and will not be replicable, causal, or lead to clinically relevant health recommendations or decisions unless they:

a. Apply basic scientific principles and record-keeping,

b. Conduct the study with human subjects,

c. Use exactly the same foods in both legs of the study,

d. Dose foods in the intervention stage using a single compound as an independent variable, 
e. Eliminate non-food exposures and other confounding environmental and stress-related psychological confounders. This includes sequestering subjects in a disciplined but human-centered dormitory environment.

With proper attention to detail, these five requirements could possibly produce clinically useful methods for precision approaches to personalized dietary interventions. ${ }^{147}$

\section{ACKNOWLEDGEMENTS}

We would like to thank Dr. Alison Abritis Ph.D. for her helpful comments and invaluable discussions and suggestions.

This study was funded by the authors and the Center for Research on Environmental Chemicals in Humans, Sonoma, CA - https://crechcenter.org/

\section{SUPPLEMENTAL MATERIAL}

Supplemental materials will be posted at https://stealthsyndromesstudy.com/ as they are formatted for upload.

\section{REFERENCES}

1. Vandenberg LN, Chahoud I, Heindel JJ, Padmanabhan V, Paumgartten FJR, Schoenfelder G. Urinary, Circulating, and Tissue Biomonitoring Studies Indicate Widespread Exposure to Bisphenol A. Cien Saude Colet. 2012;17(2):407-434. doi:10.1590/S1413-81232012000200015

2. United States Environmental Protection Agency (US EPA). TSCA Chemical Substance Inventory. US EPA. Published August 15, 2014. Accessed August 31, 2020. https://www.epa.gov/tsca-inventory

3. European Food Safety Authority (EFSA). Report of ESCO WG on non plastic FCMs. EFSA Supporting Publications. 2012;8(7):139E. doi:10.2903/sp.efsa.2011.EN-139

4. Neltner TG, Kulkarni NR, Alger HM, et al. Navigating the U.S. Food Additive Regulatory Program. Compr Rev Food Sci Food Saf. 2011;10:342-368. doi:10.1111/j.1541-4337.2011.00166.x

5. Muncke J, Myers JP, Scheringer M, Porta M. Food packaging and migration of food contact materials: will epidemiologists rise to the neotoxic challenge? J Epidemiol Community Health. 2014;68(7):592-594. doi:10.1136/jech-2013-202593

6. Centers for Disease Control and Prevention (CDC). Fourth Report on Human Exposure to Environmental Chemicals, Updated Tables. Atlanta, GA: U.S. Department of Health and Human Services, Centers for Disease Control and Prevention; 2019. Accessed August 31, 2020. https://www.cdc.gov/exposurereport/index.html

7. Vandenberg LN, Hauser R, Marcus M, Olea N, Welshons WV. Human exposure to bisphenol A (BPA). Reprod Toxicol. 2007;24(2):139-177. doi:10.1016/j.reprotox.2007.07.010

8. Bao W, Liu B, Rong S, Dai SY, Trasande L, Lehmler H-J. Association Between Bisphenol A Exposure and Risk of All-Cause and Cause-Specific Mortality in US Adults. JAMA Netw Open. 2020;3(8):e2011620-e2011620. doi:10.1001/jamanetworkopen.2020.11620 
medRxiv preprint doi: https://doi.org/10.1101/2020.10.25.20212282; this version posted October 27, 2020. The copyright holder for this preprint (which was not certified by peer review) is the author/funder, who has granted medRxiv a license to display the preprint in perpetuity. It is made available under a CC-BY-NC-ND 4.0 International license .

9. Diamanti-Kandarakis E, Bourguignon J-P, Giudice LC, et al. Endocrine-Disrupting Chemicals: An Endocrine Society Scientific Statement. Endocr Rev. 2009;30(4):293-342. doi:10.1210/er.2009-0002

10. Ferguson LR, Chen H, Collins AR, et al. Genomic instability in human cancer: Molecular insights and opportunities for therapeutic attack and prevention through diet and nutrition. Semin Cancer Biol. 2015;35:S5-S24. doi:10.1016/j.semcancer.2015.03.005

11. Keri RA, Ho S-M, Hunt PA, Knudsen KE, Soto AM, Prins GS. An evaluation of evidence for the carcinogenic activity of bisphenol A. Reprod Toxicol. 2007;24(2):240252. doi:10.1016/j.reprotox.2007.06.008

12. Fang L, Wuptra K, Chen D, et al. Environmental-stress-induced Chromatin Regulation and its Heritability. J Carcinog Mutagen. 2014;5(1). doi:10.4172/2157-2518.1000156

13. Vega A, Baptissart M, Caira F, Brugnon F, Lobaccaro J-MA, Volle DH. Epigenetic: a molecular link between testicular cancer and environmental exposures. Front Endocrinol. 2012;3. doi:10.3389/fendo.2012.00150

14. Tarapore P, Ying J, Ouyang B, Burke B, Bracken B, Ho S-M. Exposure to Bisphenol A Correlates with Early-Onset Prostate Cancer and Promotes Centrosome Amplification and Anchorage-Independent Growth In Vitro. PLoS One. 2014;9(3):e90332. doi:10.1371/journal.pone.0090332

15. Vandenberg, L.N., Hauser, R., Marcus, M., Olea, N., Welshons, W.V. 2007. Human exposure to bisphenol A (BPA). Reproductive Toxicology 24: 139-177.

16. Zhang Z, Chen S, Feng Z, Su LJ. Pregnancy Exposures Determine Risk of Breast Cancer in Multiple Generations of Offspring. In: Su LJ, Chiang T, eds. Environmental Epigenetics. Molecular and Integrative Toxicology. Springer; 2015:75-103. doi:10.1007/978-1-4471-6678-8 5

17. Gassman NR, Coskun E, Stefanick DF, et al. Bisphenol A Promotes Cell Survival Following Oxidative DNA Damage in Mouse Fibroblasts. PLoS One. 2015;10(2):e0118819. doi:10.1371/journal.pone.0118819

18. Bishop KS, Ferguson LR. The Interaction between Epigenetics, Nutrition and the Development of Cancer. Nutrients. 2015;7(2):922-947. doi:10.3390/nu7020922

19. Kim Y-S, Hwang K-A, Hyun S-H, Nam K-H, Lee C-K, Choi K-C. Bisphenol A and Nonylphenol Have the Potential to Stimulate the Migration of Ovarian Cancer Cells by Inducing Epithelial-Mesenchymal Transition via an Estrogen Receptor Dependent Pathway. Chem Res Toxicol. 2015;28(4):662-671. doi:10.1021/tx500443p

20. Nahta R, Al-Mulla F, Al-Temaimi R, et al. Mechanisms of environmental chemicals that enable the cancer hallmark of evasion of growth suppression. Carcinogenesis. 2015;36(Suppl 1):S2-S18. doi:10.1093/carcin/bgv028

21. Hajjari M, Salavaty A. HOTAIR: an oncogenic long non-coding RNA in different cancers. Cancer Biol Med. 2015;12(1):1-9. doi:10.7497/j.issn.2095-3941.2015.0006

22. Gao X, Wang H-S. Impact of Bisphenol A on the Cardiovascular System Epidemiological and Experimental Evidence and Molecular Mechanisms. Int J Environ Res Public Health. 2014;11(8):8399-8413. doi:10.3390/ijerph110808399

23. Rancière F, Lyons JG, Loh VHY, et al. Bisphenol A and the risk of cardiometabolic disorders: a systematic review with meta-analysis of the epidemiological evidence. Environmental Health. 2015;14(1):46. doi:10.1186/s12940-015-0036-5

24. Bae S, Hong Y-C. Exposure to Bisphenol A From Drinking Canned Beverages Increases Blood Pressure. Hypertension. 2015;65(2):313-319. doi:10.1161/HYPERTENSIONAHA.114.04261 
medRxiv preprint doi: https://doi.org/10.1101/2020.10.25.20212282; this version posted October 27, 2020. The copyright holder for this preprint (which was not certified by peer review) is the author/funder, who has granted medRxiv a license to display the preprint in perpetuity. It is made available under a CC-BY-NC-ND 4.0 International license .

25. Belcher SM, Chen Y, Yan S, Wang H-S. Rapid Estrogen Receptor-Mediated Mechanisms Determine the Sexually Dimorphic Sensitivity of Ventricular Myocytes to $17 \beta$-Estradiol and the Environmental Endocrine Disruptor Bisphenol A. Endocrinology. 2012;153(2):712-720. doi:10.1210/en.2011-1772

26. Gao X, Liang Q, Chen Y, Wang H-S. Molecular Mechanisms Underlying the Rapid Arrhythmogenic Action of Bisphenol A in Female Rat Hearts. Endocrinology. 2013;154(12):4607-4617. doi:10.1210/en.2013-1737

27. Liang Q, Gao X, Chen Y, Hong K, Wang H-S. Cellular Mechanism of the Nonmonotonic Dose Response of Bisphenol A in Rat Cardiac Myocytes. Environ Health Perspect. 2014;122(6):601-608. doi:10.1289/ehp.1307491

28. Melzer D, Osborne NJ, Henley WE, et al. Urinary Bisphenol A Concentration and Risk of Future Coronary Artery Disease in Apparently Healthy Men and Women. Circulation. 2012;125(12):1482-1490. doi:10.1161/CIRCULATIONAHA.111.069153

29. Yan S, Song W, Chen Y, Hong K, Rubinstein J, Wang H-S. Low-dose bisphenol A and estrogen increase ventricular arrhythmias following ischemia-reperfusion in female rat hearts. Food Chem Toxicol. 2013;56:75-80. doi:10.1016/j.fct.2013.02.011

30. Regnier SM, Sargis RM. Adipocytes under assault: Environmental disruption of adipose physiology. Biochim Biophys Acta Mol Basis Dis. 2014;1842(3):520-533. doi:10.1016/j.bbadis.2013.05.028

31. Ellero-Simatos S, Claus SP, Benelli C, et al. Combined Ellero-Simatos S, Claus SP, Benelli C, et al. Combined Transcriptomic-1H NMR Metabonomic Study Reveals That Monoethylhexyl Phthalate Stimulates Adipogenesis and Glyceroneogenesis in Human Adipocytes. J Proteome Res. 2011;10(12):5493-5502. doi:10.1021/pr200765v

32. Marmugi A, Ducheix S, Lasserre F, et al. Low doses of bisphenol a induce gene expression related to lipid synthesis and trigger triglyceride accumulation in adult mouse liver. Hepatology. 2012;55(2):395-407. doi:10.1002/hep.24685

33. Hugo Eric R., Brandebourg Terry D., Woo Jessica G., Loftus Jean, Alexander J. Wesley, Ben-Jonathan Nira. Bisphenol A at Environmentally Relevant Doses Inhibits Adiponectin Release from Human Adipose Tissue Explants and Adipocytes. Environ Health Perspect. 2008;116(12):1642-1647. doi:10.1289/ehp.11537

34. Menale C, Piccolo MT, Cirillo G, et al. Bisphenol A effects on gene expression in adipocytes from children: association with metabolic disorders. J Mol Endocrinol. 2015;54(3):289-303. doi:10.1530/JME-14-0282

35. Savastano S, Tarantino G, D'Esposito V, et al. Bisphenol-A plasma levels are related to inflammatory markers, visceral obesity and insulin-resistance: a cross-sectional study on adult male population. J Transl Med. 2015;13(1):169. doi:10.1186/s12967-015-0532-y

36. Seidlová-Wuttke D, Jarry H, Christoffel J, Rimoldi G, Wuttke W. Effects of bisphenol-A (BPA), dibutylphtalate (DBP), benzophenone-2 (BP2), procymidone (Proc), and linurone (Lin) on fat tissue, a variety of hormones and metabolic parameters: A 3 months comparison with effects of estradiol (E2) in ovariectomized (ovx) rats. Toxicology. 2005;213(1):13-24. doi:10.1016/j.tox.2005.05.001

37. Alonso-Magdalena Paloma, Morimoto Sumiko, Ripoll Cristina, Fuentes Esther, Nadal Angel. The Estrogenic Effect of Bisphenol A Disrupts Pancreatic $\beta$-Cell Function In Vivo and Induces Insulin Resistance. Environ Health Perspect. 2006;114(1):106-112. doi:10.1289/ehp.8451

38. Nadal A, Alonso-Magdalena P, Soriano S, Quesada I, Ropero AB. The pancreatic $\beta$-cell as a target of estrogens and xenoestrogens: Implications for blood glucose homeostasis and diabetes. Mol Cell Endocrinol. 2009;304(1):63-68. doi:10.1016/j.mce.2009.02.016 
medRxiv preprint doi: https://doi.org/10.1101/2020.10.25.20212282; this version posted October 27, 2020. The copyright holder for this preprint (which was not certified by peer review) is the author/funder, who has granted medRxiv a license to display the preprint in perpetuity. It is made available under a CC-BY-NC-ND 4.0 International license .

39. Bouchard L, Thibault S, Guay S-P, et al. Leptin Gene Epigenetic Adaptation to Impaired Glucose Metabolism During Pregnancy. Diabetes Care. 2010;33(11):2436-2441. doi:10.2337/dc10-1024

40. Hofmann PJ, Schomburg L, Köhrle J. Interference of Endocrine Disrupters with Thyroid Hormone Receptor-Dependent Transactivation. Toxicol Sci. 2009;110(1):125-137. doi:10.1093/toxsci/kfp086

41. Schmutzler C, Bacinski A, Gotthardt I, et al. The Ultraviolet Filter Benzophenone 2 Interferes with the Thyroid Hormone Axis in Rats and Is a Potent in Vitro Inhibitor of Human Recombinant Thyroid Peroxidase. Endocrinology. 2007;148(6):2835-2844. doi:10.1210/en.2006-1280

42. Patisaul HB. Achieving CLARITY on bisphenol A, brain and behaviour. $J$ Neuroendocrinol. 2020;32(1):e12730. doi:10.1111/jne.12730

43. Wiersielis KR, Samuels BA, Roepke TA. Perinatal exposure to bisphenol A at the intersection of stress, anxiety, and depression. Neurotoxicol Teratol. 2020;79:106884. doi:10.1016/j.ntt.2020.106884

44. Fang F, Chen D, Yu P, et al. Effects of Bisphenol A on glucose homeostasis and brain insulin signaling pathways in male mice. Gen Comp Endocrinol. 2015;212:44-50. doi:10.1016/j.ygcen.2015.01.017

45. El-Missiry MA, Othman AI, Al-Abdan MA, El-Sayed AA. Melatonin ameliorates oxidative stress, modulates death receptor pathway proteins, and protects the rat cerebrum against bisphenol-A-induced apoptosis. J Neurol Sci. 2014;347(1):251-256. doi:10.1016/j.jns.2014.10.009

46. Kundakovic M, Champagne FA. Epigenetic perspective on the developmental effects of bisphenol A. Brain Behav Immun. 2011;25(6):1084-1093. doi:10.1016/j.bbi.2011.02.005

47. Testa C, Nuti F, Hayek J, et al. Di-(2-Ethylhexyl) Phthalate and Autism Spectrum Disorders: ASN Neuro. Published online May 30, 2012. doi:10.1042/AN20120015

48. Clark-Taylor T, Clark-Taylor BE. Is autism a disorder of fatty acid metabolism? Possible dysfunction of mitochondrial $\beta$-oxidation by long chain acyl-CoA dehydrogenase. Medical Hypotheses. 2004;62(6):970-975. doi:10.1016/j.mehy.2004.01.011

49. Hannon PR, Peretz J, Flaws JA. Daily Exposure to Di(2-ethylhexyl) Phthalate Alters Estrous Cyclicity and Accelerates Primordial Follicle Recruitment Potentially Via Dysregulation of the Phosphatidylinositol 3-Kinase Signaling Pathway in Adult Mice. Biol Reprod. 2014;90(6). doi:10.1095/biolreprod.114.119032

50. Hannon PR, Flaws JA. The Effects of Phthalates on the Ovary. Front Endocrinol. 2015;6. doi:10.3389/fendo.2015.00008

51. León-Olea M, Martyniuk CJ, Orlando EF, et al. Current Concepts in Neuroendocrine Disruption. Gen Comp Endocrinol. 2014;0:158-173. doi:10.1016/j.ygcen.2014.02.005

52. Meeker JD, Ferguson KK. Urinary Phthalate Metabolites Are Associated With Decreased Serum Testosterone in Men, Women, and Children From NHANES 2011-2012. J Clin Endocrinol Metab. 2014;99(11):4346-4352. doi:10.1210/jc.2014-2555

53. Braun JM, Just AC, Williams PL, Smith KW, Calafat AM, Hauser R. Personal care product use and urinary phthalate metabolite and paraben concentrations during pregnancy among women from a fertility clinic. J Expo Sci Environ Epidemiol. 2014;24(5):459-466. doi:10.1038/jes.2013.69

54. Soares A, Guieysse B, Jefferson B, Cartmell E, Lester JN. Nonylphenol in the environment: A critical review on occurrence, fate, toxicity and treatment in wastewaters. Environ Int. 2008;34(7):1033-1049. doi:10.1016/j.envint.2008.01.004 
55. Lyche JL, Gutleb AC, Bergman $\AA$, et al. Reproductive and Developmental Toxicity of Phthalates. J Environ Sci Health B. 2009;12(4):225-249. doi:10.1080/10937400903094091

56. Wetherill YB, Akingbemi BT, Kanno J, et al. In vitro molecular mechanisms of bisphenol A action. Reproductive Toxicology. 2007;24(2):178-198. doi:10.1016/j.reprotox.2007.05.010

57. Resendiz M, Mason S, Lo C-L, Zhou FC. Epigenetic regulation of the neural transcriptome and alcohol interference during development. Front Genet. 2014;5. doi:10.3389/fgene.2014.00285

58. Mason S, Zhou FC. Editorial: Genetics and epigenetics of fetal alcohol spectrum disorders. Front Genet. 2015;6. doi:10.3389/fgene.2015.00146

59. Kim JH, Sartor MA, Rozek LS, et al. Perinatal bisphenol A exposure promotes dosedependent alterations of the mouse methylome. BMC Genomics. 2014;15(1):30. doi:10.1186/1471-2164-15-30

60. Walker CL. Epigenomic reprogramming of the developing reproductive tract and disease susceptibility in adulthood. Teratology. 2011;91(8):666-671. doi:10.1002/bdra.20827

61. Cao J, Rebuli ME, Rogers J, et al. Prenatal Bisphenol A Exposure Alters Sex-Specific Estrogen Receptor Expression in the Neonatal Rat Hypothalamus and Amygdala. Toxicol Sci. 2013;133(1):157-173. doi:10.1093/toxsci/kft035

62. Crinnion WJ. Toxic Effects of the Easily Avoidable Phthalates and Parabens. Environmental Medicine. Published online 2010:7.

63. Wang I-J, Karmaus WJ, Chen S-L, Holloway JW, Ewart S. Effects of phthalate exposure on asthma may be mediated through alterations in DNA methylation. Clinical Epigenetics. 2015;7(1):27. doi:10.1186/s13148-015-0060-x

64. Dodson Robin E., Nishioka Marcia, Standley Laurel J., Perovich Laura J., Brody Julia Green, Rudel Ruthann A. Endocrine Disruptors and Asthma-Associated Chemicals in Consumer Products. Environ Health Perspect. 2012;120(7):935-943. doi:10.1289/ehp.1104052

65. Hoppin Jane A., Jaramillo Renee, London Stephanie J., et al. Phthalate Exposure and Allergy in the U.S. Population: Results from NHANES 2005-2006. Environ Health Perspect. 2013;121(10):1129-1134. doi:10.1289/ehp.1206211

66. Wang, I.-J., Karmaus, W. J., Chen, S.-L., Holloway, J. W., and Ewart, S. 2015. Effects of phthalate exposure on asthma may be mediated through alterations in DNA methylation. Clinical Epigenetics 7(1): 27.

67. Dodson, R.E., Nishioka, M., Standley, L.J., Perovich, L.J., Brody, J.G., and Rudel, R.A. 2012. Endocrine disruptors and asthma-associated chemicals in consumer products. Environmental Health Perspectives 120(7): 935.

68. Hoppin, J.A., Jaramillo, R., London, S.J., Bertelsen, R.J., Salo, P.M., Sandler, D.P., Zeldin, D.C. 2013. Phthalate exposure and allergy in the U.S. population: results from NHANES 2005-2006. Environmental Health Perspectives 121: 1129-1134.

69. vom Saal FS, Welshons WV. Large effects from small exposures. II. The importance of positive controls in low-dose research on bisphenol A. Environmental Research. 2006;100(1):50-76. doi:10.1016/j.envres.2005.09.001

70. Baldi E, Muratori M, eds. Genetic Damage in Human Spermatozoa. 1st ed. Springer; 2014. doi:10.1007/978-1-4614-7783-9

71. Judson Richard, Richard Ann, Dix David J., et al. The Toxicity Data Landscape for Environmental Chemicals. Environ Health Perspect. 2009;117(5):685-695. doi:10.1289/ehp.0800168 
medRxiv preprint doi: https://doi.org/10.1101/2020.10.25.20212282; this version posted October 27, 2020. The copyright holder for this preprint (which was not certified by peer review) is the author/funder, who has granted medRxiv a license to display the preprint in perpetuity. It is made available under a CC-BY-NC-ND 4.0 International license .

72. National Toxicology Program (NTP). NTP Research Report on the CLARITY-BPA Core Study: A Perinatal and Chronic Extended-Dose-Range Study of Bisphenol A in Rats.; 2018:9. doi:10.22427/NTP-RR-9

73. Food and Drug Administration (FDA). Statement from Stephen Ostroff M.D., Deputy Commissioner for Foods and Veterinary Medicine, on National Toxicology Program draft report on Bisphenol A. FDA. Published March 24, 2020. Accessed September 25, 2020. https://www.fda.gov/news-events/press-announcements/statement-stephen-ostroffmd-deputy-commissioner-foods-and-veterinary-medicine-national-toxicologyy

74. Schug TT, Heindel JJ, Camacho L, et al. A new approach to synergize academic and guideline-compliant research: The CLARITY-BPA research program. Reproductive Toxicology. 2013;40:35-40. doi:10.1016/j.reprotox.2013.05.010

75. Camacho L, Lewis SM, Vanlandingham MM, et al. A two-year toxicology study of bisphenol A (BPA) in Sprague-Dawley rats: CLARITY-BPA core study results. Food Chem Toxicol. 2019;132:110728. doi:10.1016/j.fct.2019.110728

76. Abbasi J. Scientists Call FDA Statement on Bisphenol A Safety Premature. JAMA. 2018;319(16):1644-1646. doi:10.1001/jama.2018.3288

77. Vandenberg LN, Prins GS, Patisaul HB, Zoeller RT. The Use and Misuse of Historical Controls in Regulatory Toxicology: Lessons from the CLARITY-BPA Study. Endocrinology. 2020;161(5). doi:10.1210/endocr/bqz014

78. Vandenberg LN, Hunt PA, Gore AC. Endocrine disruptors and the future of toxicology testing — lessons from CLARITY-BPA. Nat Rev Endocrinol. 2019;15(6):366-374. doi:10.1038/s41574-019-0173-y

79. vom Saal FS. Flaws in design, execution and interpretation limit CLARITY-BPA's value for risk assessments of bisphenol A. BCPT. 2019;125(S3):32-43. doi:10.1111/bcpt.13195

80. Geens $\mathrm{T}$, Aerts D, Berthot $\mathrm{C}$, et al. A review of dietary and non-dietary exposure to bisphenol-A. Food Chem Toxicol. 2012;50(10):3725-3740. doi:10.1016/j.fct.2012.07.059

81. Myers SL, Yang CZ, Bittner GD, Witt KL, Tice RR, Baird DD. Estrogenic and antiestrogenic activity of off-the-shelf hair and skin care products. J Expo Sci Environ Epidemiol. 2015;25(3):271-277. doi:10.1038/jes.2014.32

82. Nam S-H, Seo Y-M, Kim M-G. Bisphenol A migration from polycarbonate baby bottle with repeated use. Chemosphere. 2010;79(9):949-952. doi:10.1016/j.chemosphere.2010.02.049

83. Biedermann S, Tschudin P, Grob K. Transfer of bisphenol A from thermal printer paper to the skin. Anal Bioanal Chem. 2010;398(1):571-576. doi:10.1007/s00216-010-3936-9

84. Ehrlich S, Calafat AM, Humblet O, Smith T, Hauser R. Handling of Thermal Receipts as a Source of Exposure to Bisphenol A. JAMA. 2014;311(8):859-860. doi:10.1001/jama.2013.283735

85. Kloukos D, Pandis N, Eliades T. In vivo bisphenol-A release from dental pit and fissure sealants: A systematic review. J Dent. 2013;41(8):659-667. doi:10.1016/j.jdent.2013.04.012

86. Duty SM, Mendonca K, Hauser R, et al. Potential Sources of Bisphenol A in the Neonatal Intensive Care Unit. Pediatrics. 2013;131(3):483-489. doi:10.1542/peds.20121380

87. Sathyanarayana S, Alcedo G, Saelens BE, et al. Unexpected results in a randomized dietary trial to reduce phthalate and bisphenol A exposures. J Expo Sci Environ Epidemiol. 2013;23(4):378-384. doi:10.1038/jes.2013.9 
88. Bhunia K, Sablani SS, Tang J, Rasco B. Migration of Chemical Compounds from Packaging Polymers during Microwave, Conventional Heat Treatment, and Storage. Compr Rev Food Sci Food Saf. 2013;12(5):523-545. doi:10.1111/1541-4337.12028

89. Rudel Ruthann A., Gray Janet M., Engel Connie L., et al. Food Packaging and Bisphenol A and Bis(2-Ethyhexyl) Phthalate Exposure: Findings from a Dietary Intervention. Environ Health Perspect. 2011;119(7):914-920. doi:10.1289/ehp.1003170

90. Bang DY, Kyung M, Kim MJ, et al. Human Risk Assessment of Endocrine-Disrupting Chemicals Derived from Plastic Food Containers. Compr Rev Food Sci Food Saf. 2012;11(5):453-470. doi:10.1111/j.1541-4337.2012.00197.x

91. Yang CZ, Yaniger SI, Jordan VC, Klein DJ, Bittner GD. Most Plastic Products Release Estrogenic Chemicals: A Potential Health Problem That Can Be Solved. Environ Health Perspect. 2011;119(7):989/96. doi:10.1289/ehp.1003220

92. Fasano E, Bono-Blay F, Cirillo T, Montuori P, Lacorte S. Migration of phthalates, alkylphenols, bisphenol A and di(2-ethylhexyl)adipate from food packaging. Food Control. 2012;27(1):132-138. doi:10.1016/j.foodcont.2012.03.005

93. Serrano SE, Braun J, Trasande L, Dills R, Sathyanarayana S. Phthalates and diet: a review of the food monitoring and epidemiology data. Environmental Health. 2014;13(1):43. doi:10.1186/1476-069X-13-43

94. Rodgers KM, Rudel RA, Just AC. Phthalates in Food Packaging, Consumer Products, and Indoor Environments. In: Snedeker SM, ed. Toxicants in Food Packaging and Household Plastics: Exposure and Health Risks to Consumers. Molecular and Integrative Toxicology. Springer; 2014:31-59. doi:10.1007/978-1-4471-6500-2_2

95. Hayasaka Y. Analysis of phthalates in wine using liquid chromatography tandem mass spectrometry combined with a hold-back column: Chromatographic strategy to avoid the influence of pre-existing phthalate contamination in a liquid chromatography system. $J$ Chromatogr A. 2014;1372:120-127. doi:10.1016/j.chroma.2014.10.096

96. Wagner M, Oehlmann J. Endocrine disruptors in bottled mineral water: total estrogenic burden and migration from plastic bottles. Environ Sci Pollut Res. 2009;16(3):278-286. doi:10.1007/s11356-009-0107-7

97. Bittner GD, Denison MS, Yang CZ, Stoner MA, He G. Chemicals having estrogenic activity can be released from some bisphenol a-free, hard and clear, thermoplastic resins. Environmental Health. 2014;13(1):103. doi:10.1186/1476-069X-13-103

98. Perdue L. How Food Processing Adds Plastic-Derived Chemical Contamination | Stealth Syndromes Human Study. Accessed September 9, 2020. https://stealthsyndromesstudy.com/?p=1276

99. Perdue L. How Does the Food Chain Get Contaminated with Plastic-Derived Chemicals (PDCs)? Stealth Syndromes Human Study. Accessed September 9, 2020. https://stealthsyndromesstudy.com/?p=1101

100. Srour B, Beslay M, Méjean C, Allès B, Fiolet T, et al.. Consumption of ultra-processed foods and the risk of overweight and obesity, and weight trajectories in the French cohort NutriNet-Santé. 13th European Nutrition Conference - Malnutrition in an obese world: European perspectives (FENS 2019), Oct 2019, Dublin, Ireland. 2019, Abstracts of the 13th European Nutrition Conference - Malnutrition in an obese world: European perspectives. 〈hal-02377022〉

101. Costa CS, Del-Ponte B, Assunção MCF, Santos IS. Consumption of ultra-processed foods and body fat during childhood and adolescence: a systematic review. Public Health Nutr. 2018;21(1):148-159. doi:10.1017/S1368980017001331 
102. Nardocci M, Leclerc B-S, Louzada M-L, Monteiro CA, Batal M, Moubarac J-C. Consumption of ultra-processed foods and obesity in Canada. Can J Public Health. 2019;110(1):4-14. doi:10.17269/s41997-018-0130-x

103. Juul F, Martinez-Steele E, Parekh N, Monteiro CA, Chang VW. Ultra-processed food consumption and excess weight among US adults. Br J Nutr. 2018;120(1):90-100. doi:10.1017/S0007114518001046

104. Mendonça R de D, Pimenta AM, Gea A, et al. Ultraprocessed food consumption and risk of overweight and obesity: the University of Navarra Follow-Up (SUN) cohort study. Am J Clin Nutr. 2016;104(5):1433-1440. doi:10.3945/ajcn.116.135004

105. Hall KD, Ayuketah A, Brychta R, et al. Ultra-Processed Diets Cause Excess

Calorie Intake and Weight Gain: An Inpatient Randomized Controlled Trial of Ad Libitum Food Intake. Cell Metabolism. 2019;30(1):67-77.e3. doi:10.1016/j.cmet.2019.05.008

106. Laster J, Frame LA. Beyond the Calories-Is the Problem in the Processing? Curr Treat Options Gastro. 2019;17(4):577-586. doi:10.1007/s11938-019-00246-1

107. Schulze K, Adams J, White M. Associations Between Sales of Ultra-Processed Food Products and Prevalence of Adiposity and Diabetes Mellitus: A Panel Analysis of 76 Countries Between 2001-2016. SSRN. 2019;Preprint. doi:10.2139/ssrn.3397190

108. Srour B, Fezeu LK, Kesse-Guyot E, et al. Ultra-processed food intake and risk of type 2 diabetes in a French cohort of middle-aged adults. Eur J Public Health. 2019;29(Supplement_4). doi:10.1093/eurpub/ckz185.388

109. Neuenschwander M, Ballon A, Weber KS, et al. Role of diet in type 2 diabetes incidence: umbrella review of meta-analyses of prospective observational studies. $B M J$. 2019;366. doi:10.1136/bmj.12368

110. Schwingshackl L, Hoffmann G, Lampousi A-M, et al. Food groups and risk of type 2 diabetes mellitus: a systematic review and meta-analysis of prospective studies. Eur J Epidemiol. 2017;32(5):363-375. doi:10.1007/s10654-017-0246-y

111. Srour B, Fezeu LK, Kesse-Guyot E, et al. Ultra-processed food intake and risk of cardiovascular disease: prospective cohort study (NutriNet-Santé). BMJ. 2019;365. doi:10.1136/bmj.11451

112. Smiljanec K. Ultra-processed Food Consumption and Vascular Health. The FASEB Journal. 2020;34(S1):1-1. doi:10.1096/fasebj.2020.34.s1.05472

113. Moreira PVL, Baraldi LG, Moubarac J-C, et al. Comparing Different Policy Scenarios to Reduce the Consumption of Ultra-Processed Foods in UK: Impact on Cardiovascular Disease Mortality Using a Modelling Approach. PLoS One. 2015;10(2):e0118353. doi:10.1371/journal.pone.0118353

114. Fiolet T, Srour B, Sellem L, et al. Consumption of ultra-processed foods and cancer risk: results from NutriNet-Santé prospective cohort. BMJ. 2018;360. doi:10.1136/bmj.k322

115. Rico-Campà A, Martínez-González MA, Alvarez-Alvarez I, et al. Association between consumption of ultra-processed foods and all cause mortality: SUN prospective cohort study. BMJ. 2019;365. doi:10.1136/bmj.11949

116. Hagobian T. CLARITY-BPA Program in Rats: Is It Translatable to Humans? $J$ Endocr Soc. 2019;3(7):1390-1392. doi:10.1210/js.2019-00126

117. Mak IW, Evaniew N, Ghert M. Lost in translation: animal models and clinical trials in cancer treatment. Am J Transl Res. 2014;6(2):114-118. 
118. Freedman LP, Cockburn IM, Simcoe TS. The Economics of Reproducibility in Preclinical Research. PLoS Biology. 2015;13(6):e1002165.

doi:10.1371/journal.pbio.1002165

119. Hartshorne JK and Schachner A. Tracking replicability as a method of postpublication open evaluation. Front. Comput. Neurosci. 2012;6:8. doi: 10.3389/fncom.2012.00008.

120. Begley CG, Ellis LM. Raise standards for preclinical cancer research. Nature. 2012;483(7391):531-533. doi:10.1038/483531a

121. Garza C, Stover PJ, Ohlhorst SD, et al. Best practices in nutrition science to earn and keep the public's trust. Am J Clin Nutr. 2019;109(1);225-243. doi:10.1093/ajen/nqy337.

122. Ioannidis JPA. Implausible results in human nutrition research. BMJ. 2013;347. doi:10.1136/bmj.f6698

123. Ridker PM. Inflammation in atherothrombosis: how to use high-sensitivity Creactive protein (hsCRP) in clinical practice. Am Heart Hosp J. 2004;2(4 Suppl 1):4-9

124. Denegri A, Boriani G. High sensitivity C-reactive protein (hsCRP) and its implications in cardiovascular outcomes [published online ahead of print, $2020 \mathrm{Jul} 16$ ]. Curr Pharm Des. 2020; doi:10.2174/1381612826666200717090334.

125. Carrero JJ, Franko MA, Obergfell A, Gabrielsen A, Jernberg T. hsCRP Level the Risk of Death or Recurrent Cardiovascular Events in Patients With Myocardial Infarction: a Healthcare-Based Study. JAHA. 2019;8(11):e012638; doi:10.1161/JAHA.119.012638

126. Lancellotti P, Marechal P, Donis N, Oury C. Inflammation, cardiovascular disease, and cancer: a common link with far-reaching implications. Eur Heart J. 2019;40(48):3910-3912. doi:10.1093/eurheartj/ehz645.

127. Denegri A, Boriani G. High sensitivity C-reactive protein (hsCRP) and its implications in cardiovascular outcomes [published online ahead of print, $2020 \mathrm{Jul} 16$ ]. Curr Pharm Des. 2020;10.2174/1381612826666200717090334. doi:10.2174/1381612826666200717090334

128. Ebrahimi M, Heidari-Bakavoli AR, Shoeibi S, et al. Association of Serum hsCRP Levels With the Presence of Obesity, Diabetes Mellitus, and Other Cardiovascular Risk Factors. J Clin Lab Anal. 2016;30(5):672-676. doi:10.1002/jcla.21920

129. Muller DC, Larose TL, Hodge A, et al. Circulating high sensitivity C reactive protein concentrations and risk of lung cancer: nested case-control study within Lung Cancer Cohort Consortium. BMJ. 2019;364:k4981. Published 2019 Jan 3. doi:10.1136/bmj.k4981

130. Luan YY, Yao YM. The Clinical Significance and Potential Role of C-Reactive Protein in Chronic Inflammatory and Neurodegenerative Diseases. Front Immunol. 2018;9:1302. Published 2018 Jun 7. doi:10.3389/fimmu.2018.01302

131. Nadrowski P, Chudek J, Skrzypek M, et al. Associations between cardiovascular disease risk factors and IL-6 and hsCRP levels in the elderly. Exp Gerontol. 2016;85:112117. doi:10.1016/j.exger.2016.10.001

132. Lai KSP, Liu CS, Rau A, et al. Peripheral inflammatory markers in Alzheimer's disease: a systematic review and meta-analysis of 175 studies. J Neurol Neurosurg Psychiatry. 2017;88(10):876-882. doi:10.1136/jnnp-2017-316201

133. O'Donovan A, Rush G, Hoatam G, et al. Suicidal ideation is associated with elevated inflammation in patients with major depressive disorder. Depress Anxiety. 2013;30(4):307-314. doi:10.1002/da.22087 
134. Mocking RJT, Nap TS, Westerink AM, et al. Biological profiling of prospective antidepressant response in major depressive disorder: Associations with (neuro)inflammation, fatty acid metabolism, and amygdala-reactivity. Psychoneuroendocrinology. 2017;79:84-92. doi:10.1016/j.psyneuen.2017.02.019

135. Courtet P, Giner L, Seneque M, Guillaume S, Olie E, Ducasse D. Neuroinflammation in suicide: Toward a comprehensive model. World J Biol Psychiatry. 2016;17(8):564-586. doi:10.3109/15622975.2015.1054879

136. Brundin L, Erhardt S, Bryleva EY, Achtyes ED, Postolache TT. The role of inflammation in suicidal behaviour. Acta Psychiatr Scand. 2015;132(3):192-203. doi:10.1111/acps. 12458

137. Connelly MA, Gruppen EG, Otvos JD, Dullaart RPF. Inflammatory glycoproteins in cardiometabolic disorders, autoimmune diseases and cancer. Clin Chim Acta. 2016;459:177-186. doi:10.1016/j.cca.2016.06.012

138. Lochhead P, Khalili H, Ananthakrishnan AN, Richter JM, Chan AT. Association Between Circulating Levels of C-Reactive Protein and Interleukin-6 and Risk of Inflammatory Bowel Disease. Clin Gastroenterol Hepatol. 2016;14(6):818-824.e6. doi:10.1016/j.cgh.2016.01.016

139. Chen S, Ma BL, Cao MQ, Yu HJ, Ma XM. [Correlation among serum MBL, MASP-2, HsCRP and C3 levels in rheumatoid arthritis].Nan Fang Yi Ke Da Xue Xue Bao. 2016;36(10):1340-1344.

140. Zhang TL, Niu JF, Liu JT, Hu TY, Li Q[Value of hsCRP and Alb in Evaluating the Prognosis of Patients with Systemic Lupus Erythematosus]. Zhongguo Shi Yan Xue Ye Xue Za Zhi. 2017;25(4):1218-1222. doi:10.7534/j.issn.1009-2137.2017.04.045

141. Panchanathan R, Liu H, Leung Y-K, Ho S, Choubey D. Bisphenol A (BPA) stimulates the interferon signaling and activates the inflammasome activity in myeloid cells. Mol Cell Endocrinol. 2015;415:45-55. doi:10.1016/j.mce.2015.08.003

142. Roche JA, Roche R. A hypothesized role for dysregulated bradykinin signaling in COVID-19 respiratory complications. FASEB Journal. 2020;34(6):7265-7269. doi:10.1096/fj.202000967

143. Ratajczak MZ, Kucia M. SARS-CoV-2 infection and overactivation of N1rp3 inflammasome as a trigger of cytokine "storm" and risk factor for damage of hematopoietic stem cells. Leukemia. 2020;34(7):1726-1729. doi:10.1038/s41375-0200887-9

144. Shah A. Novel Coronavirus-Induced NLRP3 Inflammasome Activation: A Potential Drug Target in the Treatment of COVID-19. Front Immunol. 2020;11. doi:10.3389/fimmu.2020.01021

145. Freeman TL, Swartz TH. Targeting the NLRP3 Inflammasome in Severe COVID19. Front Immunol. 2020;11. doi:10.3389/fimmu.2020.01518

146. Porcino AJ, Shamseer L, Chan A-W, et al. SPIRIT extension and elaboration for n-of-1 trials: SPENT 2019 checklist. BMJ. 2020;368. doi:10.1136/bmj.m122

147. De Roos B, Brennan L. Personalised Interventions-A Precision Approach for the Next Generation of Dietary Intervention Studies. Nutrients. 2017;9(8):847. doi:10.3390/nu9080847

148. Perdue L. Revised Stealth Syndromes Human Study Protocol - APPENDIX 2 Detailed parameters of intervention diet selections | Stealth Syndromes Human Study. Accessed September 9, 2020. https://stealthsyndromesstudy.com/?p=1270 
149. Hamrick S., Karen and McClelland, Ket. Americans' Eating Patterns and Time Spent on Food: The 2014 Eating \& Health Module Data, EIB-158, U.S. Department of Agriculture, Economic Research Service, July 2016.

150. Peixoto D, Pinheiro C, Amorim J, Oliva-Teles L, Guilhermino L, Vieira MN. Microplastic pollution in commercial salt for human consumption: A review. Estuar Coast Shelf Sci. 2019;219:161-168. doi:10.1016/j.ecss.2019.02.018

151. Hutter H-P, Kundi M, Hohenblum P, et al. Life without plastic: A family experiment and biomonitoring study. Environmental Research. 2016;150:639-644. doi:10.1016/j.envres.2016.05.028

152. Galloway TS, Baglin N, Lee BP, et al. An engaged research study to assess the effect of a 'real-world' dietary intervention on urinary bisphenol A (BPA) levels in teenagers. BMJ Open. 2018;8(2):e018742. doi:10.1136/bmjopen-2017-018742

153. Sorkin BC, Kuszak AJ, Williamson JS, Hopp DC, Betz JM. The Challenge of Reproducibility and Accuracy in Nutrition Research: Resources and Pitfalls. Adv Nutr. 2016;7(2):383-389. doi:10.3945/an.115.010595

154. Barabási A-L, Menichetti G, Loscalzo J. The unmapped chemical complexity of our diet. Nature Food. 2020;1(1):33-37. doi:10.1038/s43016-019-0005-1

155. Stahlhut RW, Welshons WV, Swan SH. Bisphenol A Data in NHANES Suggest Longer than Expected Half-Life, Substantial Nonfood Exposure, or Both. Environ Health Perspect. 2009;117(5):784-789. doi:10.1289/ehp.0800376

156. Lagarde F, Beausoleil C, Belcher SM, et al. Non-monotonic dose-response relationships and endocrine disruptors: a qualitative method of assessment. Environmental Health. 2015;14(1):13. doi:10.1186/1476-069X-14-13

157. Vandenberg LN, Colborn T, Hayes TB, et al. Hormones and EndocrineDisrupting Chemicals: Low-Dose Effects and Nonmonotonic Dose Responses. Endocrine Reviews. 2012;33(3):378-455. doi:10.1210/er.2011-1050

158. Ohlwein S, Kappeler R, Kutlar Joss M, Künzli N, Hoffmann B. Health effects of ultrafine particles: a systematic literature review update of epidemiological evidence. Int J Public Health. 2019;64(4):547-559. doi:10.1007/s00038-019-01202-7 